Factores que influyen en el aprendizaje en línea de estudiantes universitarios bajo la pandemia covid-19

\title{
Factors influencing online learning of university students under the covid-19 pandemic
}

Faisal Mustafa. University of Central Punjab, Pakistan. faisal.mustafa@ucp.edu.pk

Ambreen Khursheed. University of Central Punjab, Pakistan. ambreen.khursheed@ucp.edu.pk

Syed Muhammad Usama Rizvi. Osamarizvi10@hotmail.com

\author{
Ahsan Zahid. \\ ahsanzahid182@gmail.com \\ Ayesha Akhtar. \\ ayeshaakhtar@ucp.edu.pk
}

\section{RESUMEN.}

Los sistemas de aprendizaje en línea, por su naturaleza, están libres de restricciones de tiempo o de lugar y pueden resultar una plataforma útil para los estudiantes en la que pueden continuar sus estudios cuando no les es posible ir a una universidad en persona por diferentes razones. Esos sistemas también se han utilizado en el Pakistán, en particular en el sector privado, para la educación universitaria y escolar. Este artículo intenta destacar varios problemas que enfrentan los estudiantes y los factores que tienen un efecto significativo en su experiencia de aprendizaje en línea. Recopilamos datos a través de cuestionarios en línea distribuidos a 1200 estudiantes matriculados en seis universidades privadas en Pakistán. Este estudio empleó el Modelado de Ecuación de Estructura (SEM) para examinar factores que influyeron en el aprendizaje en línea. Los resultados mostraron que la enseñanza y el comportamiento profesional, la planificación y metodología de la enseñanza de cursos y la conectividad en línea se asociaban significativamente positivamente con el aprendizaje en línea. Con la identificación de los factores clave que afectan el aprendizaje en línea de los estudiantes, será más útil ofrecer mejores servicios para una efectiva formación de los estudiantes. En el documento también se examinan otras consecuencias cruciales y un camino a seguir.

\section{PALABRAS CLAVE.}

Aprendizaje en línea, Pakistán, modelación de ecuaciones estructurales, educación.

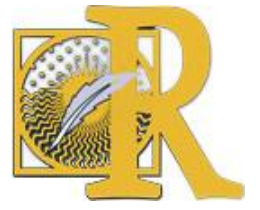

Fecha de recepción: 17-11-2020 Fecha de aceptación: 21-11-2020 


\section{ABSTRACT.}

Online learning systems owing to their nature are free of restrictions of time or place and can prove to be a useful platform for students where they can continue their studies when it is not possible for them to go to a university in person owing to different reasons. Such systems have also been used in Pakistan, particularly in private sector, for university and school education. This paper attempts to highlight various issues that the students are facing and the factors that have a significant effect on their online learning experience. We collected data through online questionnaires distributed to 1200 students enrolled in six private universities in Pakistan. This study employed the Structure Equation Modelling (SEM) to examine factors that influenced online learning. The results showed that teaching and professional behaviour, course instructional planning and methodology and online connectivity were significantly positively associated with online learning. With the identification of key factors that affects online learning of students, it will be more helpful to provide improved services for effective student leaning. Other crucial implications and a way forward are also discussed in the paper.

\section{KEY WORDS.}

Online learning, Pakistan, Structural equation modelling, Education.

\section{Introduction.}

The outbreak of the recent pandemic, COVID-19, in December 2019 in Wuhan city has not only affected the global economy (Lu, Stratton \& Tang, 2020) but also changed life as we knew it. It has affected over 170 countries including US, UK, Italy, Pakistan and many others (World Health Organization, 2020). Given the connected and integrated nature of contemporary world, the performance key sectors have been disrupted due to COVID-19 outbreak, and the education sector is one of the most badly affected sectors (McKibbin \& Fernando, 2020). Therefore, a serious concern has been raised for every country as the evolution of this pandemic and its economic impact has drastically changed the professional routines and operational working pattern of various sectors respectively (Wang, et al. 2020). COVID-19 has disrupted almost every section of life. The developed as well as developing nations are now in the search of finding new ways to manage the core business activities of every affected sector. The high uncertainty of COVID-19 makes it complicated for the policy makers to design a suitable solution as response to current pandemic situation particularly for the education sector. It is one of the most prominent sectors that has badly affected with COVID-19 outbreak (Loayza \& Pennings, 2020). The universities and secondary education institutions all around the world are now alarmed as the exact estimation of the departure of COVID-19 seems impossible (Crawford et al. 2020).

Moreover, COVID-19 has not only disrupted the global education services but also raised a major question for educators: to ensure the operational continuity, development and progress of the industry. This has started a string of innovative ideas particularly amongst the education sector to neutralize or reduce the effect of this pandemic on students and their study. Therefore, in this study we aim to explore the impact of Covid-19 on the education sector by examining the current online learning system. In particular, when we talk about the impact of COVID-19 outbreak on education sector, the developed countries have formulated many

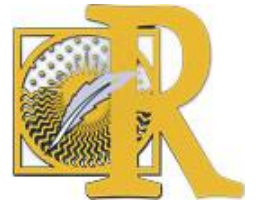

Fecha de recepción: 17-11-2020 Fecha de aceptación: 21-11-2020

Mustafa, F., Khursheed, A., Usama-Rizvi, S. M., Zahid, A. \& Akhtar, A. (2021). Factores que influyen en el aprendizaje en línea de estudiantes universitarios bajo la pandemia covid-19 International Journal of Educational Research and Innovation (IJERI), 15, 342-359 ISSN: 2386-4303 DOI https://doi.org/10.46661/ijeri.5432 
fruitful strategies to manage their educational setup (Ukpokodu, 2020). Whereas, the developing countries are far behind in doing the proper management of their education sector due to lack of resources, expertise and weak infrastructure (Liguori \& Winkler, 2020). Pakistan falls in the category of developing countries and the outbreak of COVID-19 has forced universities there to switch to online classes as Ministry of Education ordered a lockdown (Zhang, 2020). Currently, many private universities are providing education and management services online with the use of technology but various issues related to virtual education environment have come to their attention, while several public education institutions in different countries are still working to establish their online platforms and are also trying to eliminate the visible obstacles of virtual learning system.

The adoption of technology in education sector is not a new concept as contemporary computer technologies such as online learning and other tools have been used in various forms already. However, the demand of technology and online platforms for teaching has extensively increased during current global plague. Technology not only flourishes new ways of teaching but also enhances the quality of learning experiences (Bielawski \& Metcalf, 2005). An interesting research conducted by independent research companies revealed that the corporate education market contributed $16 \%$ of reserves on the overall online learning initiatives in 2000. Technology itself is an opportunity that helps in the evolution of corporate learning at all levels of education, particularly higher education (Abdelmeneim, Said, Hassan, \& Malek, 2000).

Nowadays, the nature of the global education environment is very competitive. In this era of digital ubiquity, the development of Internet-based computerized learning, namely online learning is the key focus of all educators (Goodman et al. 2019). Online learning is defined as "the use of advanced multimedia technology and the Internet to improve the learning process by offering accessible resources and services, along with distant communication and collaboration" (Freeze et al. 2019). The term online learning can also be expressed as "the use of network-based advanced technologies to produce, adopt, deliver and smooth the learning process, anytime and anywhere in the entire globe" (Kung, 2019). Online learning can be optimized only when it becomes assisted and personalized (Gell-Mann, 1996). As per the definition of online learning, it is a combination of different technologies (Wu, et al., 2010), in which computers are the most important components that work as the potential saviours of the virtual education system. The reason behind is that computers can be supportive to personalise virtual learning. They have enough capacity to formulate our learning procedures according to our needs and existing knowledge. Computers are highly able to record our overall progress report and let us know about any wrong thought process so that we can make corrections accordingly (Hayashi et al. 2020). Therefore, the availability of computer systems holds a critical significance while implementing virtual/online education.

Furthermore, online learning is a comprehensive learning approach that provides a choice to the leaner to select any kind of learning method (Hasnat, 2009), and can help in the development of individual as well as societal knowledge for any country. In this digital age, the quality education and active learning through online learning seem as key success factors (Siddiqui, Saeed, \& Farid, 2019; Vohra, 2013). Therefore, in the current situation Pakistan is keenly interested in adopting online learning education system at all levels, particularly by

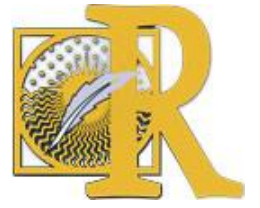

Fecha de recepción: 17-11-2020 Fecha de aceptación: 21-11-2020

Mustafa, F., Khursheed, A., Usama-Rizvi, S. M., Zahid, A. \& Akhtar, A. (2021). Factores que influyen en el aprendizaje en línea de estudiantes universitarios bajo la pandemia covid-19 International Journal of Educational Research and Innovation (IJERI), 15, 342-359 ISSN: 2386-4303 DOI https://doi.org/10.46661/ijeri.5432 
following the trend of other developed countries. However, due to the lack of technology and its improper installation, the element of customization, another key component of online systems, is missing from the current models being implemented subsequently affecting the productivity of both, students and teachers.

Particularly, when we talk about universities all around the world, their main purpose is independent thinking, working and learning. In a virtual environment, a learner is able to develop all these competencies. Therefore, online learning can directly change the working pattern of students (Goodman, Melkers, \& Pallais, 2019), as it is the transference of internal and external knowledge through information technology in order to enhance the quality of leaning and intellectual capacity of students. In this way, the significance of online learning seems as a future work demand (Willems, Farley, \& Campbell, 2019). However, any change in leaning procedure needs a change in the core teaching staff as well. A new and fastened learning culture is required in the everyday life of students and teaching staff. Prospect teachers should develop the necessary competencies to become familiar with technology and to learn its adequate use for integrating the class into various subject disciplines (Loyalka, Popova, \& Shi, 2019). Thus, a well-planned and realistic policy is needed for strategy, technology, faculty and proper implementation process in order to cater all the above discussed issues. As with the help of such policy, learners will broaden their interest on knowledge community-based online learning (Ruey-Shun, 2007). Many other concerns are also present in virtual learning system that need to be examined carefully, but the study of Bennet et al. (1999), Torrisi-Steele (2002), Neo and Neo (2001) and Bryceson (2001) revealed that the actual technology of delivery is not that much vital, but the way of teachers for using that technology to create new learning experiences for the students is the most significant factor in establishing a good learning environment.

Moreover, the growing corpus of literature also argues the need to find out internet-based learning solutions that are transparently grounded in virtual learning system to ensure a highquality and flexible learning environment (McMahon 1997; Ring and McMahon 1997; Pear and Crone-Todd 2002; Neo and Neo 2001). The study of Martins and Kellermanns (2004) reported that online course management system boosts students' participation (i.e. through technology awareness and new means of communication). Online learning system and software based technology provide easy approach to various online resources to students along with a maximum user control. Therefore, students may fail to effectively engage themselves due to having complete freedom in browsing the web course. Also, student's individual differences is another factor that can disturb the online learning (Graf \& Kinshuk, 2010). In this way, the cognitive abilities of student can directly affect the virtual learning. A study of Stash (2007) indicate that student's psychological traits and browsing behaviour are correlated with each other. Further, to establish the proper attention of students in online courses is the main obstacle of online learning system. When we see this current global COVID-19 epidemic situation, all higher education institutions and universities operating in Pakistan have shifted to a long-distance online teaching platform simultaneously. Whereas, the teaching staff, the platform operators, and departments of universities have not fully examined the scale of this newly epidemic explosion. The huge increase in the use of online teaching platform has raised major problems for both university management and teaching

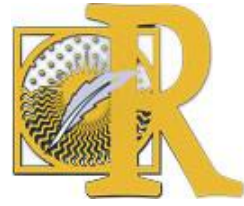

Fecha de recepción: 17-11-2020 Fecha de aceptación: 21-11-2020

Mustafa, F., Khursheed, A., Usama-Rizvi, S. M., Zahid, A. \& Akhtar, A. (2021). Factores que influyen en el aprendizaje en línea de estudiantes universitarios bajo la pandemia covid-19 International Journal of Educational Research and Innovation (IJERI), 15, 342-359 ISSN: 2386-4303 DOI https://doi.org/10.46661/ijeri.5432 
staff. Also, various issues related to the pre-construction and implementation process of all university staff switching to virtual teaching platform are being highlighted and is now a cause of serious concern. Therefore, in this study we aim to fill the existing research gap by determining the impact of key factors affecting online learning of students under the pandemic in Pakistan. This study aims to address the key issues of online learning system linked with establishing appropriate and realistic mechanisms for improving as well as expanding the learning in an online education system in Pakistan. Following hypothesis are deduced from the extant literature.

\section{H1: Teaching \& Professional Behavior influences online learning}

H2: Course Instructional Planning \& Methodology affects online learning.

H3: Online connectivity and availability affects online learning.

H4: Student engagement methods influence online learning.

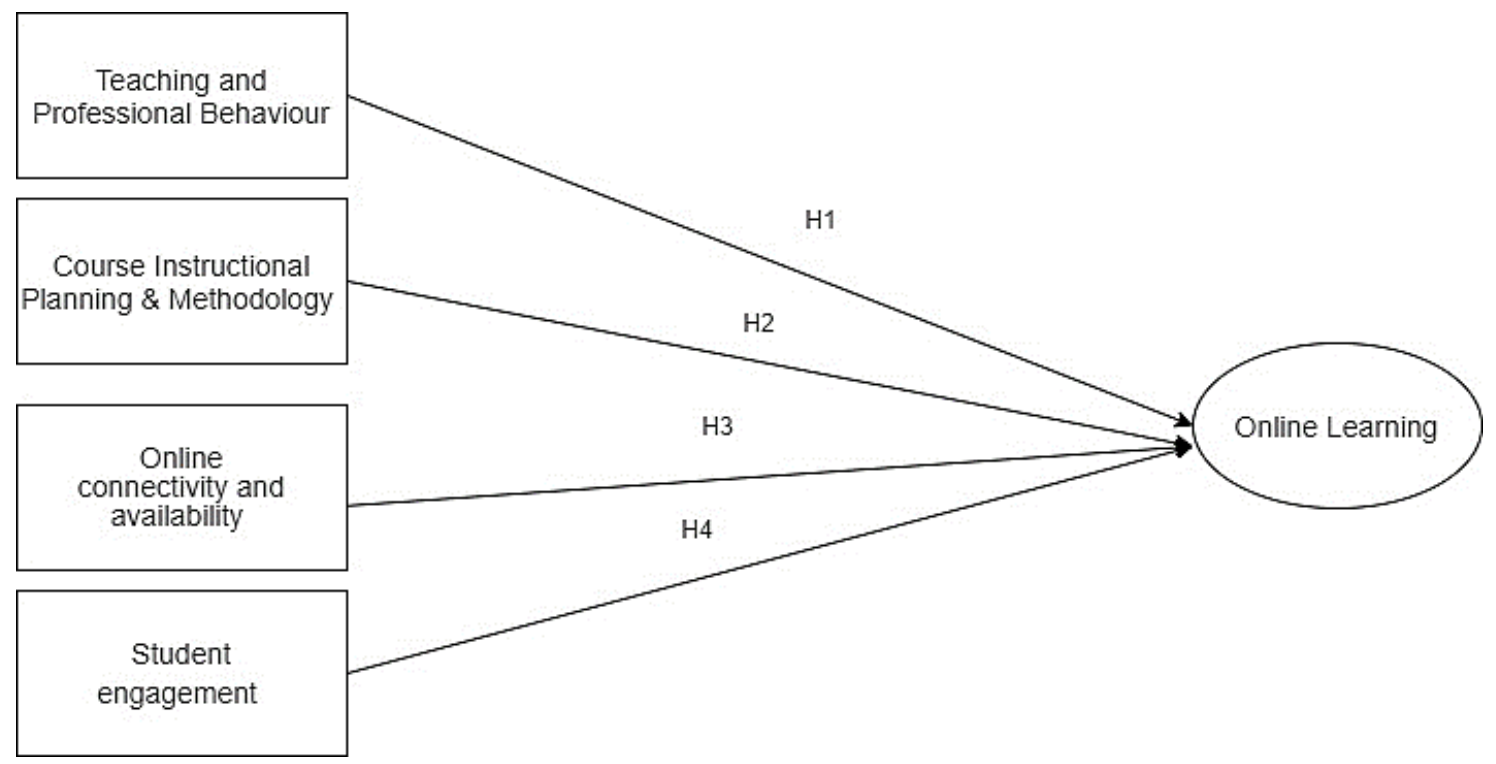

Fig.1. Proposed conceptual Framework of the study.

\section{Research Methodology.}

This section includes the research design and data analysis method. At first, the demographic characteristics of the respondents are discussed. Afterwards, the methods applied for analyzing the collected data are presented. Thirdly, the selected data analytic technique is discussed. Various characteristics were used to categorize the respondents after the collection of the questionnaires, including factors that affected Pakistan's education system in this pandemic. In this study, the sample size comprised of 1200 students. $43 \%$ of students had no laptop or computer at their home. $56 \%$ of students had no high speed internet coverage. $26 \%$ of students dropped their course due to unavailability of resources. Degree of $31 \%$ got delayed and $54 \%$ of students reported that teachers are effective in delivering online

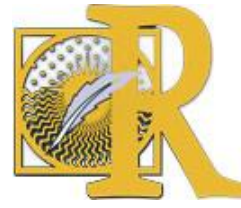

Fecha de recepción: 17-11-2020 Fecha de aceptación: 21-11-2020

Mustafa, F., Khursheed, A., Usama-Rizvi, S. M., Zahid, A. \& Akhtar, A. (2021). Factores que influyen en el aprendizaje en línea de estudiantes universitarios bajo la pandemia covid-19 
lectures. 53\% of students were satisfied with the assessment methodology of teachers. $33 \%$ of students expressed that they are fully engaged in online lectures. $64 \%$ of students were slightly $\sim$ moderately comfortable to bear their educational expenses due to the effect of Covid-19 on their mother/father business or employment. As universities across Pakistan using online education system, $61 \%$ of students said they are not enjoying working with their group in this online learning system. $58 \%$ of students said their interaction with other virtual students is very low low. 52\% students said their confidence level on completing knowledge on subjects learned online is very low low \& $46 \%$ said confidence level is average.

\section{Survey Structure.}

To measure the impact of COVID-19 on university education we have used an online questionnaire to collect data. This is a primary study and data has been collected from six private universities in Pakistan. We received 1200 responses in total. The dependent construct is online learning and independent constructs include teaching and professional behavior, course instructional planning \& methodology, online connectivity and availability and student engagement. The first section of the questionnaire comprises of questions related to personal data in addition to the questions related to internet connectivity. The second section comprises of four questions related to online learning system. The third section consists of four questions related to teaching and professional behavior. The fourth section consists of five questions on course instructional planning \& methodology. The fifth section comprises of five questions about online connectivity and availability. Finally, the sixth section comprises of four questions on student engagement. A five-point likert scale is used ranging from strongly agree to strongly disagree.

\section{Empirical Results.}

Online learning is considered as an effective tool in designing learning and teaching methods for higher education. However, the success of online learning is totally dependent on the student acceptability of this technology. If the student is uncomfortable in using this technology, then it is unable to help students to properly grow in a virtual learning system. Thus, the aim of this study is to analyze the possible factors that impact the effective learning of students by focusing on the issues faced by university students.

\section{Valuation of the Measurement Model.}

We adopted the measurement model for elaborating the linkage between latent construct and the indicators. These two rationalities showed that the adopted model is a good fit (Joo et al., 2014).

\section{Convergent Validity.}

There are two well-known methods widely used to analyze convergent validity. In the first method, the loadings of the individual measures to their conforming constructs were done. Second method is used to examine the composite reliabilities (Ashill and Jobber, 2010). We used Partial Least Squares (Smart PLS ver. 3.2.6) for the testing procedure of convergent validity. Two distinctive analysis were executed in our study. The preliminary PLS is performed

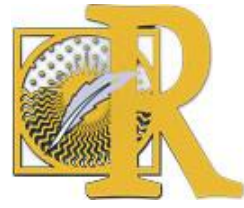

Fecha de recepción: 17-11-2020 Fecha de aceptación: 21-11-2020

Mustafa, F., Khursheed, A., Usama-Rizvi, S. M., Zahid, A. \& Akhtar, A. (2021). Factores que influyen en el aprendizaje en línea de estudiantes universitarios bajo la pandemia covid-19 International Journal of Educational Research and Innovation (IJERI), 15, 342-359 ISSN: 2386-4303 DOI https://doi.org/10.46661/ijeri.5432 
with the help of boot strapping procedure (300 resamples) designed loadings, composite reliabilities (CR), weights, average variance extracted (AVE) and also t-values for each individual measurement element corresponding to its imagined construct are used. After that, a detailed analysis of each measurement element was conducted (Hair et al., 2016). It was observed that every element showed higher value of loading than the recommended value of 0.70. The loadings for the measurement elements are seen much higher than the recommended value of 0.70 . This difference indicates that over $50 \%$ of the variance is distributed between the measurement element and its suggested construct defined in hypothesis (Barclay et al., 1995). Table 1 represents the details of consequential number of elements for each construct, CR and AVE values (Vinzi et al., 2010). A satisfactory internal consistency is found in the composite reliability as the values are above 0.80 (Nunnally \& Bernstein, 1994). The values of CR are in the range of $0.804-0.927$, that are aligned with the recommended value of 0.80 .

Table 1. Results of measurements model - convergent validity.

\begin{tabular}{|c|c|c|c|c|}
\hline Construct & Items & $\begin{array}{l}\text { Factor } \\
\text { loading } \\
\text { (Construct } \\
\text { Validity) }\end{array}$ & $\begin{array}{l}\text { Composite } \\
\text { Reliability }\end{array}$ & $\begin{array}{l}\text { Average } \\
\text { Variance } \\
\text { Extracted } \\
\text { (AVE) }\end{array}$ \\
\hline $\begin{array}{l}\text { Teaching and } \\
\text { professional } \\
\text { behavior }\end{array}$ & $\begin{array}{l}\text { TBB1 } \\
\text { TPB2 } \\
\text { TPB3 } \\
\text { TPB4 }\end{array}$ & $\begin{array}{l}0.801 \\
0.824 \\
0.832 \\
0.898\end{array}$ & 0.856 & 0.733 \\
\hline $\begin{array}{l}\text { Course } \\
\text { instructional } \\
\text { planning \& } \\
\text { methodology }\end{array}$ & $\begin{array}{l}\text { CIPM1 } \\
\text { CIPM2 } \\
\text { CIPM3 } \\
\text { CIPM4 } \\
\text { CIPM5 }\end{array}$ & $\begin{array}{l}0.852 \\
0.881 \\
0.856 \\
0.895 \\
0.805\end{array}$ & 0.860 & 0.687 \\
\hline $\begin{array}{l}\text { Online } \\
\text { connectivity and } \\
\text { availability }\end{array}$ & $\begin{array}{l}\text { OCA1 } \\
\text { OCA2 } \\
\text { OCA3 } \\
\text { OCA4 } \\
\text { OCA5 }\end{array}$ & $\begin{array}{l}0.823 \\
0.869 \\
0.857 \\
0.884 \\
0.865\end{array}$ & 0.815 & 0.701 \\
\hline $\begin{array}{l}\text { Student } \\
\text { engagement }\end{array}$ & $\begin{array}{l}\text { SE1 } \\
\text { SE2 } \\
\text { SE3 } \\
\text { SE4 }\end{array}$ & $\begin{array}{l}0.758 \\
0.881 \\
0869 \\
0.874\end{array}$ & 0.804 & 0.725 \\
\hline Online learning & $\begin{array}{l}\text { OTP1 } \\
\text { OTP2 } \\
\text { OTP3 } \\
\text { OTP4 }\end{array}$ & $\begin{array}{l}0.825 \\
0.836 \\
0.862 \\
0.891\end{array}$ & 0.927 & 0.695 \\
\hline
\end{tabular}

Factor Loadings $>(0.7)$, Composite reliability $>(0.7), A V G>(0.5)$

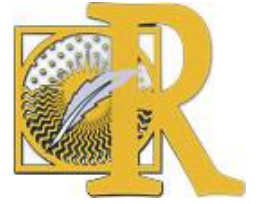




\section{Discriminant Validity.}

Discriminant validity helps in determining the construct (Chin, 1998) when it differs from all other constructs in the research framework (Matias-Reche et al., 2008). There are two methods to demonstrate the discriminant validity. First of all, the relationship between the latent variable with its indicators were examined because the discriminant validity could only be determined by forming different constructing measures. The measures are expected to show rigorous loadings on their hypothesized construct rather than other constructs that are the part of research framework. It indicates that the loadings should be greater matched to the cross loadings (Hair et al., 2016).

We used AVE to ensure that every individual construct has a high percentage of variance with its indicators matched to the other unobservable variables in the research framework. Also, it should be above the value of 0.5 (Storey \& Kahn, 2010; Chin, 1998; Fornell and Bookstein, 1982). This study selected the cross-loadings and the Fornell-Larcker scale for the assessment of discriminant validity. Table 2 provides the analysis of Fornell-Larcker scale. The bold diagonal figures of the table are used to indicate the square root of the average variance extracted score (Abu-Al-Aish, 2014). On the other hand, the off-load diagonal figure are used to explain the associations between the constructs. Table 3 shows the cross-loading values. In the light of a related research study, it has been observed that the cross-loadings and the loadings exhibit that all the measurement elements load broadly on their own latent constructs rather than using other constructs for the loading purpose (Cheng and Chen, 2015).

Table 2. Discriminant validity results.

\begin{tabular}{|c|c|c|c|c|c|}
\hline Variable & $\begin{array}{l}\text { Teaching } \\
\text { pedagogy }\end{array}$ & $\begin{array}{l}\text { Teaching \& } \\
\text { Professional } \\
\text { Behavior }\end{array}$ & $\begin{array}{l}\text { Course } \\
\text { Instructional } \\
\text { Planning \& } \\
\text { Methodology }\end{array}$ & $\begin{array}{l}\text { online } \\
\text { connectivity and } \\
\text { availability }\end{array}$ & $\begin{array}{l}\text { Students' } \\
\text { Engagement }\end{array}$ \\
\hline $\begin{array}{l}\text { Teaching } \\
\text { pedagogy }\end{array}$ & 0.895 & & & & \\
\hline $\begin{array}{l}\text { Teaching \& } \\
\text { Professional } \\
\text { Behavior }\end{array}$ & 0.654 & 0.841 & & & \\
\hline $\begin{array}{l}\text { Course } \\
\text { Instructional } \\
\text { Planning \& } \\
\text { Methodology }\end{array}$ & 0.689 & 0.652 & 0.856 & & \\
\hline $\begin{array}{l}\text { online } \\
\text { connectivity and } \\
\text { availability }\end{array}$ & 0.754 & 0.733 & 0.845 & 0.901 & \\
\hline $\begin{array}{l}\text { Students' } \\
\text { Engagement }\end{array}$ & 0.710 & 0.789 & 0.771 & 0.752 & 0.822 \\
\hline
\end{tabular}

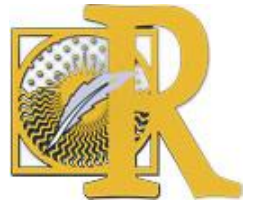




\section{Assessment of Structural Model (Inner Model).}

In the first phase, we assessed the appropriateness of the measurement model. Whereas, in the second phase, we performed the structural modelling analysis and testing procedure for hypothesis (Harun et al., 2015). The structural model gives some recommendations. One suggestion is that there is the presence of a casual linkage between the latent constructs of the research framework. The path coefficients are primarily used to assess the capacity of the hypothesized linkages. Figure 2 presents the path coefficient results.

Table 3. Results of discriminant validity - cross loadings.

\begin{tabular}{llllll}
\hline Items & $\begin{array}{l}\text { Teaching } \\
\text { \& }\end{array}$ & $\begin{array}{l}\text { Course } \\
\text { Instructional }\end{array}$ & $\begin{array}{l}\text { Online } \\
\text { connectivit } \\
\text { Profession } \\
\text { alanning \& } \\
\text { y and } \\
\text { avehavior }\end{array}$ & $\begin{array}{l}\text { Student } \\
\text { Methodolog } \\
\text { availability }\end{array}$ & Online learning \\
y & \multicolumn{3}{l}{ nt } & \\
\hline TBB1 & $\mathbf{0 . 8 0 1}$ & 0.523 & 0.632 & 0.710 & \\
TPB2 & $\mathbf{0 . 8 2 4}$ & 0.547 & 0.689 & 0.658 & 0.751 \\
TPB3 & $\mathbf{0 . 8 3 2}$ & 0.625 & 0.667 & 0.745 & 0.687 \\
TPB4 & $\mathbf{0 . 8 9 8}$ & 0.755 & 0.699 & 0.789 & 0.609 \\
CIPM1 & 0.632 & $\mathbf{0 . 8 5 2}$ & 0.708 & 0.711 & 0.665 \\
CIPM2 & 0.658 & $\mathbf{0 . 8 8 1}$ & 0.745 & 0.706 & 0.702 \\
CIPM3 & 0.652 & $\mathbf{0 . 8 5 6}$ & 0.798 & 0.619 & 0.750 \\
CIPM4 & 0.608 & $\mathbf{0 . 8 9 5}$ & 0.655 & 0.717 & 0.658 \\
CIPM5 & 0.659 & $\mathbf{0 . 8 0 5}$ & 0.751 & 0.728 & 0.694 \\
OCA1 & 0.623 & 0.628 & $\mathbf{0 . 8 2 3}$ & 0.689 & 0.690 \\
OCA2 & 0.658 & 0.699 & $\mathbf{0 . 8 6 9}$ & 0.650 & 0.654 \\
OCA3 & 0.617 & 0.704 & $\mathbf{0 . 8 5 7}$ & 0.753 & 0.749 \\
OCA4 & 0.740 & 0.756 & $\mathbf{0 . 8 8 4}$ & 0.799 & 0.655 \\
OCA5 & 0.659 & 0.688 & $\mathbf{0 . 8 6 5}$ & 0.711 & 0.693 \\
SE1 & 0.699 & 0.785 & 0.691 & $\mathbf{0 . 7 5 8}$ & 0.666 \\
SE2 & 0.655 & 0.696 & 0.654 & $\mathbf{0 . 8 8 1}$ & 0.651 \\
SE3 & 0.698 & 0.723 & 0.668 & $\mathbf{0 8 6 9}$ & 0.744 \\
SE4 & 0.507 & 0.756 & 0.669 & $\mathbf{0 . 8 7 4}$ & 0.699 \\
OTP1 & 0.652 & 0.745 & 0.625 & 0.665 & $\mathbf{0 . 8 2 5}$ \\
OTP2 & 0.660 & 0.795 & 0.688 & 0.698 & $\mathbf{0 . 8 3 6}$ \\
OTP3 & 0.690 & 0.659 & 0.602 & 0.776 & $\mathbf{0 . 8 6 2}$ \\
OTP4 & 0.698 & 0.701 & 0.750 & 0.753 & $\mathbf{0 . 8 9 1}$
\end{tabular}




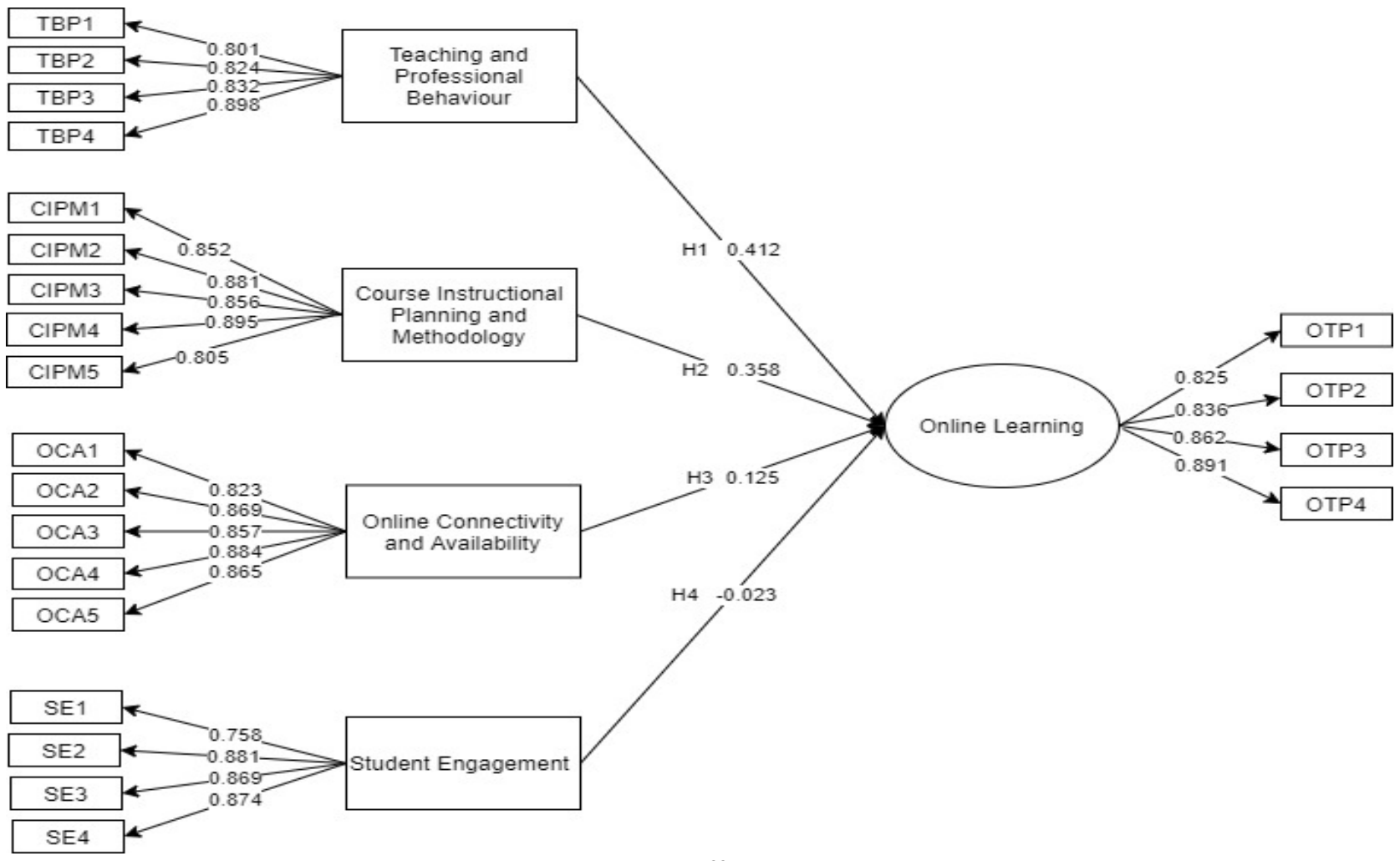

Fig.2. Path coefficient results.

\section{Coefficient of Determination $\left(R_{2}\right)$.}

Coefficient of determination $\left(R_{2}\right)$ is applied to examine the structural model (Dreheeb et al., 2016). It plays an important role in examining the predictive appropriateness of the model (Roky \& Al Meriouh, 2015). Therefore, it is a tool that also presents the variance in the endogenous constructs accepted by each individual exogenous construct associated with it. In our study, all constructs revealed the value of R2 greater than 0.70 , which is acceptable (Chin, 1998).

Table 4. Hypotheses testing results.

\begin{tabular}{llllll}
\hline Sr. No. & Hypothesis & Beta & T-value & P-value & Decision \\
\hline 1 & H1 & 0.412 & 2.013 & 0.001 & Accepted \\
2 & H2 & 0.358 & 2.857 & 0.004 & Accepted \\
3 & H3 & 0.125 & 1.988 & 0.002 & Accepted \\
4 & H4 & -0.023 & 0.011 & 0.315 & Rejected \\
\hline
\end{tabular}




\section{Findings and Discussion.}

This paper examines the key factors that influences online learning of university students under the pandemic of Covid-19. The paper helps to understand to what extent the techniques and online system currently being used is sufficient in effective learning of students. We identified that teaching \& professional behaviour is one of the most important elements that influenced the online learning effectiveness (Álvarez, Guasch, \& Espasa, 2009; Gartmeier et al. 2015). The studies done so far have manifested that efficient teaching \& professional behaviour helps students to adapt online learning system (Noesgaard, \& Ørngreen, 2015). The commitment and seriousness of the instructor affects in turn the commitment of the students. Our study finds a strong correlation between an instructor's professionalism, behavior, availability and interaction with students.

In case of second construct, it is found that instructional planning \& methodology significantly and positively impacts the effectiveness of the online learning. Therefore, to increase effectiveness and sustainability of online learning systems the instructors should focus on including a clear course outline and maintain relevance of the quizzes and assignments given to students. The instructor's way of managing the courses, workload on students and the relevance of the material being taught to the practical world; all of this will play an important role in planning and methodology of any subject (Baker, 2010). Also, as the interaction on online systems is totally different from face-to-face lectures. Therefore, many new variables (discussed below) will affect planning and methodology of a course. Thus, instructors should focus on all these elements while teaching an online course on a web based system (AlSamarraie et al. 2018). Thus, our findings reveal that virtual platform of learning provides many opportunities for teachers which they can apply for increasing the effectiveness of online learning. This finding is consistent with the results of the past studies (Wang \& Wang, 2009; Chen \& Tseng, 2012).

The results also revealed that online connectivity and availability significantly and positively affected the effectiveness of online learning. Online connectivity, and availability of systems in this model, can be termed as the prerequisites for an acceptable and effective learning system. Thus, we found that a strong and stable internet connection, recorded video lectures, clear audio and internet speed plays a crucial role in enhancing online learning as it connects students with teachers through the system. These results are consistent with past papers that have concluded that online platforms paly an effective role by enhancing in person interactions to deliver online lectures (Pham et al. 2019; Masrom, Zainon, \& Rahiman, 2008).

Finally in relation to the fourth construct, we found an insignificant and negative link between student engagement and its relationship with the effectiveness of online learning. The reason behind this may be that students equipped with different technological skills may not be interested in the tools being used by the teachers for academic student engagement. Because at present majority of students are addicted to the online games and social media apps, this may distract students and will ultimately cause less involvement in the course and this negatively influences online learning. Therefore, we recommend that teachers should simulate or use real-world problems to create an interesting situation, and help students be more involved in online environments, further improve their learning effects and develop practical

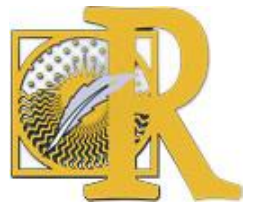

Fecha de recepción: 17-11-2020 Fecha de aceptación: 21-11-2020

Mustafa, F., Khursheed, A., Usama-Rizvi, S. M., Zahid, A. \& Akhtar, A. (2021). Factores que influyen en el aprendizaje en línea de estudiantes universitarios bajo la pandemia covid-19 International Journal of Educational Research and Innovation (IJERI), 15, 342-359 ISSN: 2386-4303 DOI https://doi.org/10.46661/ijeri.5432 
skills. These findings find support in results reported by (Jacobsen \& Forste's 2011; Wentworth \& Middleton, 2014; Lepp et al. 2014).

\section{Implications of the results.}

There are various implications of our results. First of all our conceptual model and results can be applied to online learning platforms and works for everyone regardless of their gender and level of previous educational achievements. The level of teacher's involvement and his behaviour towards the course and students have a huge effect on the effectiveness of online learning systems (Rashid \& Asghar, 2016). We also found that if the course content is not properly outlined and/or contains irrelevant topics the effectiveness of learning goes down. Another implication is that the institutions should consider training teachers and other support staff for trouble shooting and contingency planning in order to enhance the usage of such systems.

\section{Conclusion.}

The purpose of this study was to measure the impact of COVID-19 on higher education as the systems moved from in-person to online mode of teaching. We highlighted certain factors and measured their impact on student's learning. In order to analyze the collected data from 1200 students we used structural equation modelling. Correlation between 4 constructs namely; teaching \& professional behaviour, course instructional planning \& methodology, online connectivity and availability and student engagement were examined.

In this study, we have pointed that for the development and improvement of an effective online learning system, we should first focus on the issues rising due to online system. Therefore, we examined four key issues that influenced online learning of students. It was found that the first three factors have a significant and positive relationship on overall effectiveness online learning systems. All examined factors are recognized as crucial factors that significantly affects students' learning and our findings are consistent with the findings of past studies (Fisher et al., 1981; Muijis et al., 2014; Poulou, 2020; Lawler, Joseph \& Yegnaseshan, 2020; Torres-Gordillo et al., 2020)

This study is the first of its kind that has analyzed the impact of key influential factors affecting online learning during Covid-19 in Pakistan. Specifically, this study is important for universities to manage effectively the online learning system in the existing pandemic situation which is causing a paradigm shift in the education sector of Pakistan. Due to COVID-19 universities faced several challenges and were unable to continue the normal procedure, in this aspect, the present study provided an empirical analysis on the key issues faced by students during online classes. The findings of this study will help academicians to develop an effective online learning system which can add value in university teaching methodologies.

Mainly, this study has crucial implications for the government of Pakistan, as in the current pandemic, universities are unable to apply the existing teaching methodologies in the online system. This study has unique contribution in the existing literature as it not only highlights the prevailing issues but also provided a solution, that by focusing on improving teaching and professional behavior, course instructional planning \& methodology, and online connectivity and availability, university management can improve and expand online learning.

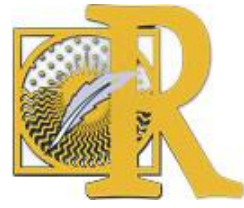


The findings can provide a basis for the formation of improved online learning systems that may develop online learning systems more acceptable to students. Further, it may boost innovative IT based platforms that create channels to support students in effective online learning. As when students have a flexible and supportive learning environment, then their academic performance will simultaneously improve. This study has vital implications for the literature. As this study proposed a comprehensive framework of key issues along with significant insights for tackling a paradigm shift in the education sector. Therefore, the designers and developers of online learning systems should consider the characteristic of teacher's professional behavior, course instructional planning \& methodology and online connectivity and availability for improving online learning system.

This study, like others, has some limitations and future directions. First of all this study examined the impact of COVID-19 on higher education by doing a survey study on six private universities of Pakistan. Replicating this study in other universities in Pakistan can add more value to the results and discussion. Here is also a need to study and analyze online education per se in detail and there hasn't been much work done on Pakistan. Second, a total of only 1200 students participated in this study. For future studies, students and universities from other countries across the world should also be included. The results will be more comprehensive and representative if the overall sample size can be increased. Also, due to certain constraints no interviews or focus groups were formed. Third, the findings of this study are mainly generalizable with the developing countries. Therefore, future studies should be focused on developed countries by using the proposed framework of this study. Fourth, this study is survey based, however, to get deeper insights about the issues of online learning, future studies should consider interviews and focus group discussions (FGDs) with university management. Finally, more studies are required to analyze student's attitudes and teacher's preparedness towards pedagogy.

\section{References.}

- Abdelmeneim, A., Said, F., Hassan, N., \& Malek, K. (2000). Training teachers at a distance on using technology in class. World-bank and Ministry of Education. Cairo: Dar El-Tyseer. (in Arabic).

- Abu-Al-Aish, A. (2014). Toward mobile learning deployment in higher education. Doctoral dissertation, Brunel University, School of Information Systems, Computing and Mathematics.

- Al-Samarraie, H., Teng, B. K., Alzahrani, A. I., \& Alalwan, N. (2018). Online learning continuance satisfaction in higher education: a unified perspective from instructors and students. Studies in Higher Education, 43(11), 2003-2019.

- Álvarez, I., Guasch, T., \& Espasa, A. (2009). University teacher roles and competencies in online learning environments: a theoretical analysis of teaching and learning practices. European Journal of Teacher Education, 32(3), 321-336.

- Anderson, J. C., \& Gerbing, D. W. (1988). Structural equation modeling in practice: A review and recommended two-step approach. Psychological Bulletin, 103(3), 411-423.

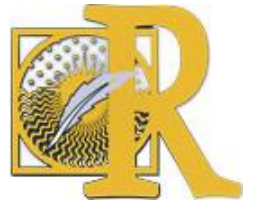

Fecha de recepción: 17-11-2020 Fecha de aceptación: 21-11-2020

Mustafa, F., Khursheed, A., Usama-Rizvi, S. M., Zahid, A. \& Akhtar, A. (2021). Factores que influyen en el aprendizaje en línea de estudiantes universitarios bajo la pandemia covid-19 International Journal of Educational Research and Innovation (IJERI), 15, 342-359 ISSN: 2386-4303 DOI https://doi.org/10.46661/ijeri.5432 
- Ashill, N. J., \& Jobber, D. (2010). Measuring State, Effect, and Response Uncertainty: Theoretical Construct Development and Empirical Validation. Journal of Management, 36(5), 1278-1308.

- Baker, C. (2010). The impact of instructor immediacy and presence for online student affective learning, cognition, and motivation. Journal of Educators Online, 7(1), 1.

- Barclay, D., Higgins, C., \& Thompson, R. (1995). The partial least squares (PLS) approach to casual modeling: personal computer adoption and use as an Illustration.

- Bennet, S., Priest, A., \& Macpherson, C. (1999). Learning about online learning: An approach to staff development for university teachers. Australian Journal of Educational Technology, 15, 207-221.

- Bielawski, L., \& Metcalf, D. (2005). Blended online learning: Integrating knowledge, performance, support, and online learning (2nd ed.). United States: HRD Press.

- Bryceson, K. (2001). Thoughts of a first-time online course developer: Issues and resolutions. Teaching \& Education News, 11(1). Retrieved from: http://www.tedi.uq.edu.au/TEN

- Cheah, J.-H., Sarstedt, M., Ringle, C.M., Ramayah, T. and Ting, H. (2018), "Convergent validity assessment of formatively measured constructs in PLS-SEM: On using single-item versus multi-item measures in redundancy analyses". International Journal of Contemporary Hospitality Management, 30 (11), 3192-3210.

- Chen, H. R., \& Tseng, H. F. (2012). Factors that influence acceptance of online online learning systems for the in-service education of junior high school teachers in Taiwan. Evaluation and Program Planning, 35(3), 398-406.

- Chen, Y. C., Wu, J. H., Peng, L., \& Yeh, R. C. (2015). Consumer benefit creation in online group buying: The social capital and platform synergy effect and the mediating role of participation. Electronic Commerce Research and Applications, 14(6), 499-513.

- Chin, W. W. (1998). The partial least squares approach to structural equation modeling. Modern methods for business research, 295(2), 295-336.

- Crawford, J., Butler-Henderson, K., Rudolph, J., \& Glowatz, M. (2020). COVID-19: 20 Countries' Higher Education Intra-Period Digital Pedagogy Responses. Journal of Applied Teaching and Learning (JALT), 3(1), 9-28.

- Detlev N. (2016). Wissensmedien und die vermittlung zwischen externer und interner repräsenration, in: Knowledge und media design. Oldenbourg Verlag, Rosenheimer str. 145, D-8 1671 München.

- Dreheeb, A. E., Basir, N., \& Fabil, N. (2016). Comparative Study of Quality Models. International Journal of Computer Science and Electronics Engineering (IJCSEE), 4(1), 35-39.

- EC [European Commission]. (2001). Communication from the commission to the council and the European parliament: the online learning action plan, Brussels, 28.3.

- Falk, R. F., \& Miller, N. B. (1992). A primer for soft modeling. University of Akron Press.

- Fisher, C. W., Berliner, D. C., Filby, N. N., Marliave, R., Cahen, L. S., \& Dishaw, M. M. (1981). Teaching behaviors, academic learning time, and student achievement: An overview. The Journal of classroom interaction, 17(1), 2-15.

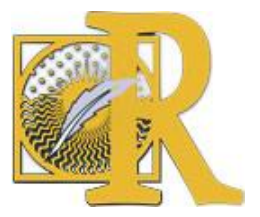


- Fornell, C., \& Bookstein, F. L. (1982). Two structural equation models: LISREL and PLS applied to consumer exit-voice theory. Journal of Marketing Research, 19(4), 440-452.

- Freeze, R. D., Alshare, K. A., Lane, P. L., \& Wen, H. J. (2019). IS success model in online learning context based on students' perceptions. Journal of Information Systems Education, 21(2), 4.

- Fregonese, C., Caputo, A., \& Langher, V. (2018). Work symbolic motive scale: development and validation of a measure of affective investment at work. International Journal of Work Organisation and Emotion, 9(4), 322-347.

- Gartmeier, M., Bauer, J., Fischer, M. R., Hoppe-Seyler, T., Karsten, G., Kiessling, C. \& Prenzel, M. (2015). Fostering professional communication skills of future physicians and teachers: effects of online learning with video cases and role-play. Instructional Science, 43(4), 443-462.

- Gell-Mann, M. (1996). A commentary to R Schank. in J. Brockman (Ed.), The third culture: beyond the scientific revolution. New York: Touchtone Books, 167-180.

- Goodman, J., Melkers, J., \& Pallais, A. (2019). Can online delivery increase access to education? Journal of Labor Economics, 37(1), 1-34.

- Graf, S., \& Kinshuk, T.-C. L. (2010). Analysis of learners' navigational behaviour and their learning styles in an online course. Journal of Computer Assisted Learning, 26(2), 116-131

- Hasnat, F. (2009) Developing an online learning environment for CSE-110 at BRAC University. A Thesis Report. Department of Computer Science and Engineering, BRAC University.

- Hayashi, A., Chen, C., Ryan, T., \& Wu, J. (2020). The role of social presence and moderating role of computer self-efficacy in predicting the continuance usage of online learning systems. Journal of Information Systems Education, 15(2), 5.

- Jacobsen, W. C., \& Forste, R. (2011). The wired generation: Academic and social outcomes of electronic media use among university students. Cyberpsychology, Behavior, and Social Networking, 14(5), 275-280.

- Joo, Y. J., Lee, H.W., \& Ham, Y. (2014). Integrating user interface and personal innovativeness into the TAM for mobile learning in Cyber University. Journal of Computing in Higher Education, 26(2), 143-158.

- Kung, Y. L. (2019). An online learning system for introduction to information and communication technology.

- Lawler, J., Joseph, A., \& Yegnaseshan, A. (2020). An Analysis of Course Impacts from a Design Factory Methodology. In Proceedings of the EDSIG Conference (Vol. 2473, p. 4901).

- Lepp, A., Barkley, J. E., \& Karpinski, A. C. (2014). The relationship between cell phone use, academic performance, anxiety, and satisfaction with life in college students. Computers in Human Behavior, 31, 343-350.

- Liguori, E., \& Winkler, C. (2020). From Offline to Online: Challenges and opportunities for entrepreneurship education following the COVID-19 pandemic. Entrepreneurship Education and Pedagogy, 3(4), 346-351.

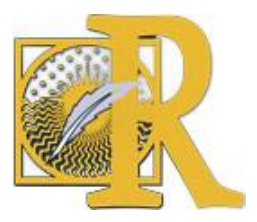


- Loayza, N. V., \& Pennings, S. (2020). Macroeconomic policy in the time of covid-19: A primer for developing countries. Research and Policy Briefs, 28.

- Loyalka, P., Popova, A., Li, G., \& Shi, Z. (2019). Does teacher training actually work? Evidence from a large-scale randomized evaluation of a national teacher training program. American Economic Journal: Applied Economics, 11(3), 128-54.

- Lu, H., Stratton, C. W., \& Tang, Y. W. (2020). The Wuhan SARS-CoV-2-What's next for China. Journal of Medical Virology, 92(6), 546-547.

- Martins, L., \& Kellermanns, F. (2004). A model of business school students' acceptance of a Online course management system. Academy of Management Learning \& Education, 3(1), 7-26.

- Masrom, M., Zainon, O., \& Rahiman, R. (2008). Critical success in online learning: An examination of technological and institutional support factors. Retrieved from: https://www.researchgate.net/publication/228410786 Critical Success in Elearning An Examination of Technological and Institutional Support Factors

- Matias-Reche, F., Garcia-Morales, V. J., \& Rueda-Manzanares, A. (2008). Entrepreneurial size, complexity and decentralization of decision-making in the use of temporary help workers in Spain. The International Journal of Human Resource Management, 19(1), 169187.

- McKibbin, W. J., \& Fernando, R. (2020). The global macroeconomic impacts of COVID-19: Seven scenarios. Retrieved form: https://www.brookings.edu/research/the-globalmacroeconomic-impacts-of-covid-19-seven-scenarios/

- McMahon, M. (1997, December). Social constructivism and the world wide web-A paradigm for learning. Paper presented at the annual meeting of the Australasian society for computers in learning in tertiary education (ASCILITE), Perth, Australia. Retrieved from: http://www.ascilite.org.au/conferences/perth97/papers/Mcmahon/Mcmahon.html

- Muijs, D., Kyriakides, L., Van der Werf, G., Creemers, B., Timperley, H., \& Earl, L. (2014). State of the art-teacher effectiveness and professional learning. School effectiveness and school improvement, 25(2), 231-256.

- Neo, K. T. K., \& Neo, M. (2001). A constructivist learning experience: Reconstructing a web site using online multimedia authoring tools. Australian Journal of Educational Technology, 17(3), 330-350.

- Noesgaard, S. S., \& Ørngreen, R. (2015). The Effectiveness of Online learning: An Explorative and Integrative Review of the Definitions, Methodologies and Factors that Promote online learning Effectiveness. Electronic Journal of Online learning, 13(4), 278290.

- Nunnally, J. C., \& Bernstein, I. H. (1994). Validity. Psychometric Theory, 3, 99-132.

- Pear, J. J., \& Crone-Todd, D. E. (2002). A social constructivist approach to computermediated instruction. Computers and Education, 38, 221-231.

- Pham, L., Limbu, Y. B., Bui, T. K., Nguyen, H. T., \& Pham, H. T. (2019). Does online learning service quality influence online learning student satisfaction and loyalty? Evidence from Vietnam. International Journal of Educational Technology in Higher Education, 16(1), 7.

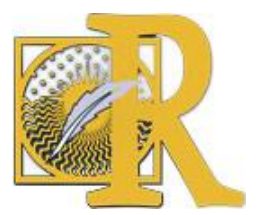


- Poulou, M. S. (2020). Students' adjustment at school: The role of teachers' need satisfaction, teacher-student relationships and student well-being. School Psychology International, 0143034320951911.

- Rashid, T., \& Asghar, H. M. (2016). Technology use, self-directed learning, student engagement and academic performance: Examining the interrelations. Computers in Human Behavior, 63, 604-612.

- Ring, G., \& McMahon, M. (1997, December). Web instruction: Searching for a theoretical basis. Paper presented at the international conference on computers in education (ICCE97), Kuching, Malaysia.

- Roky, H., \& Al Meriouh, Y. (2015). Evaluation by users of an industrial information system (XPPS) based on the DeLone and McLean model for IS success. Procedia Economics and Finance, 26, 903-913.

- Ruey-Shun, Hsiang, C. H. (2007) A study on the critical success factors for corporations embarking on knowledge community-based online learning. Information Sciences, 177 (2) 570-586.

- Siddiqui, M. U. A., Saeed, H., \& Farid, S. (2019). Online Support Services in Online learning: A Technology Acceptance Model. Sukkur IBA Journal of Computing and Mathematical Sciences, 2(2), 22-29.

- Stash, N. (2007). Incorporating Cognitive/Learning Styles in a General-Purpose Adaptive Hypermedia System. Ph.D. dissertation, Eindhoven: Technische Universiteit, Eindhoven, Netherlands.

- Storey, C., \& Kahn, K. B. (2010). The role of knowledge management strategies and task knowledge in stimulating service innovation. Journal of Service Research, 13(4), 397-410.

- Torres-Gordillo, J. J., Melero-Aguilar, N., \& García-Jiménez, J. (2020). Improving the university teaching-learning process with ECO methodology: Teachers' perceptions. PloS one, 15(8), e0237712.

- Torrisi-Steele, G. (2002, July). Technology for the sake of learning-A planning approach for integrating new technologies in tertiary learning environments. In Proceedings of AusWeb02 The Eighth Australian World Wide Web Conference.

- Ukpokodu, O. N. (2020). Marginalization of Social Studies Teacher Preparation for Global Competence and Global Perspectives Pedagogy: A Call for Change. Journal of International Social Studies, 10(1), 3-34.

- Vohra, M. H. (2013). Online learning in Pakistan. Retrieved from: http://www.hamariweb.com/articles/article.aspx?id=32766

- Wang, D., Hu, B., Hu, C., Zhu, F., Liu, X., Zhang, J., \& Zhao, et al. (2020). Clinical characteristics of 138 hospitalized patients with 2019 novel coronavirus-infected pneumonia in Wuhan, China. Jama, 323(11), 1061-1069.

- Wang, W. T., \& Wang, C. C. (2009). An empirical study of instructor adoption of online learning systems. Computers \& Education, 53(3), 761-774.

- Wentworth, D. K., \& Middleton, J. H. (2014). Technology use and academic performance. Computers \& Education, 78, 306-311.

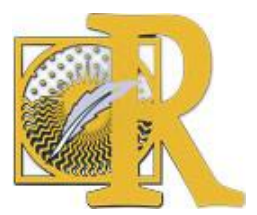


- Willems, J., Farley, H., \& Campbell, C. (2019). The increasing significance of digital equity in higher education. Australasian Journal of Educational Technology, 35(6), 1-8.

- Williams, L. J., \& Hazer, J. T. (1986). Antecedents and consequences of satisfaction and commitment in turnover models: A reanalysis using latent variable structural equation methods. Journal of Applied Psychology, 71(2), 219-231. https://doi.org/10.1037/0021$\underline{9010.71 .2 .219}$

- Wu, J., Zhang, S. (2010). Broadband multimedia online learning system using web service. Retrieved from: https://www.cn.apan.net/cairns/NRW/06-Wu\%20Jie.pdf

- Zhang, X. (2020, March). Thoughts on Large-Scale Long-Distance Online Teaching in Colleges and Universities Under Novel Coronavirus Pneumonia Epidemic: A Case of Chengdu University. In 4th International Conference on Culture, Education and Economic Development of Modern Society (ICCESE 2020) (pp. 1222-1225). Atlantis Press. 